\title{
Pulmonology
}

\section{Polymorphisms of Genes Involved in Endothelial Dysfunction in the Yakuts with COPD and Metabolic Syndrome}

\author{
Ekaterina P. Borisova, PhD*; Elena S. Kylbanova, PhD, ScD; Alexandra S. Asekritova, PhD; \\ Nadezhda R. Maksimova, PhD, ScD; Varvara N. Neustroeva, PhD; \\ Ulyana S. Portnyagina, PhD; Ara A. Donskaya, PhD, ScD \\ M. K. Ammosov North-Eastern Federal University \\ Yakutsk, the Republic of Sakha (Yakutia), Russia
}

\begin{abstract}
The aim of our research was to study the association of the $-6754 \mathrm{G} / 5 \mathrm{G}$ (rs1799889) SNP of the SERPINE1 (PAI-1) gene and the Arg353Gln G>A (rs6046) SNP of the F7 gene with metabolic syndrome (MetS) in the Yakuts with COPD.

Methods and Results: A molecular-genetic examination was conducted in 200 COPD patients of Yakut ethnicity. The main group (MG) consisted of 100 COPD patients with MetS, the comparison group (CG) included 100 COPD patients without MetS. The distribution of genotypes of studied SNPs was in Hardy-Weinberg equilibrium in all cases. Studying the SERPINE1 -675 $4 \mathrm{G} / 5 \mathrm{G}$ SNP, we found the prevalence of a $4 \mathrm{G}$ allele in $\mathrm{MG}$, compared to $\mathrm{CG}\left(\mathrm{OR}=1.84,95 \% \mathrm{CI} 1.23-2.74 ; \chi^{2}=9.06, P=0.003\right)$. Incidence of the homozygous $4 \mathrm{G} / 4 \mathrm{G}$ mutation was rather high in $\mathrm{MG}$, compared to $\mathrm{CG}\left(\mathrm{OR}=2.35,95 \% \mathrm{CI} 1.24-4.44 ; \chi^{2}=9.31\right.$, $P=0.002$ ). According to our data, the presence of MetS in Yakut patients with COPD has been associated with the carrier of the 4G/4G genotype. Studying the F7 Arg353Gln SNP, we found the prevalence of an Arg253 allele in both groups $(0.72$ in MG and 0.71 in $\left.\mathrm{CG} ; \chi^{2}=0.01, P=0.91\right)$. The homozygous Gln353/Gln353 mutant genotype was rare in both groups ( 0.12 in $\mathrm{MG}$ and 0.10 in CG; OR=1.23, 95\% CI 0.50-2.99; $\chi^{2}=0.01, P=0.92$ ). In our study, the $\mathrm{F} 7 \mathrm{Arg} 353 \mathrm{Gln}$ SNP was not associated with protection against MetS in COPD patients. (International Journal of Biomedicine. 2018;8(2):134-138.)
\end{abstract}

Key Words: SERPINE1 gene $・$ F7 gene $\bullet$ metabolic syndrome $・$ chronic obstructive pulmonary disease

\section{Abbreviations}

BMI, body mass index; ED, endothelial dysfunction; F7, coagulation factor VII; MetS, metabolic syndrome; COPD, chronic obstructive pulmonary disease; PAI-1, plasminogen activator inhibitor-1; SNP, single nucleotide polymorphism; WC, waist circumference.

\section{Introduction}

COPD is a major source of morbidity and mortality internationally. ${ }^{(1)}$ In 1997 , COPD was predicted to become the third leading cause of global death by $2020,{ }^{(2)}$ but a subsequent analysis found that COPD had become the third leading cause of global death by 2010. ${ }^{(3)}$ According to Global Strategy For The Diagnosis, Management, And Prevention Of Chronic Obstructive Pulmonary Disease (GOLD, 2017), COPD has

*Corresponding author: Ekaterina P. Borisova, PhD M.K. Ammosov North-Eastern Federal University, Yakutsk, the Republic of Sakha (Yakutia),Russia.E-mail: borisovaep75@mail.ru substantial manifestations beyond the lungs - the so-called systemic effects. ${ }^{(4)}$ The chronic systemic inflammation that is linked to COPD may also initiate or exacerbate comorbid diseases, such as cardiovascular disease, osteoporosis, anemia, MetS, type 2 diabetes, lung cancer, and depression. It is one of the key mechanisms underlying these extrapulmonary effects. ${ }^{(5-7)}$ The active involvement of the vascular endothelium in the inflammatory process is recognized in this disease. ${ }^{(8)}$ Metabolic abnormalities like type 2 diabetes, obesity and MetS are common in COPD. ${ }^{(9)}$ Obesity, physical inactivity, cigarette smoking, corticosteroid use, as well as inflammation and hypoxia, are mechanisms responsible for the development of MetS in COPD patients. ${ }^{(10-14)}$ 
MetS is a prothrombotic condition as a result of ED and an imbalance between coagulation factors and substances regulating fibrinolysis. ${ }^{(15)}$ It is known that the development of MetS is due to both environmental factors and genetic predisposition. An important point in the study of MetS is the identification of its characteristics in different ethnic groups, since the peculiarities of culture and lifestyle determine the genetic aberrations that lead to MetS development. ${ }^{(16)}$ The study of genetic determinants in the development of MetS in COPD patients is of undoubted interest.

Currently, there are no data on the association of SNPs in genes, related to $\mathrm{ED}$, in particular, $-6754 \mathrm{G} / 5 \mathrm{G}$ insertion/deletion promoter polymorphism (rs1799889) of the SERPINE1 (PAI-1) gene and Arg353Gln polymorphism of the F7 gene, with MetS in Yakut people with COPD.

PAI-1 also known as endothelial plasminogen activator inhibitor, encoded by the SERPINE1 gene, is an inhibitor of fibrinolysis ${ }^{(17)}$ and, as such, genetic mutations of SERPINE1 resulting in alterations in plasma levels or function of the expressed protein may be important determinants for COPD and MetS.

Previous studies have suggested that a single guanosine insertion/deletion $(4 \mathrm{G} / 5 \mathrm{G})$ polymorphism in the promoter region is associated with circulating levels of PAI-1. ${ }^{(18)}$ Studies carried out in different populations have consistently shown that individuals, homozygous for the $4 \mathrm{G}$ allele, have significantly higher plasma PAI-1 levels than those homozygous for the $5 \mathrm{G}$ allele. ${ }^{(19)}$ This SNP is associated with the risk of insulin resistance and thrombosis formation. ${ }^{(20,21)}$

Factor VII (FVII), a vitamin K-dependent glycoprotein secreted by the liver, plays an important role in the initiation of coagulation by tissue factor. ${ }^{(22)}$ Plasma FVIIc levels are regulated by environmental factors, such as age, BMI, dietary fat intake, plasma lipids, especially triglycerides, and diabetes, ${ }^{(23-25)}$ and by a genetic component. ${ }^{(26,27)}$

The F7 Arg353Gln SNP located in exon 8 causes an exchange of arginine to glutamine, which in turn results in decreased FVII activity by $20 \%$ to $30 \%{ }^{(28-30)}$ It has been suggested that the Gln 353 allele protects against myocardial infarction. ${ }^{(28)}$ Thus, presence of the Gln353 allele may consequently also be protective in other situations in which thrombus formation is a fundamental pathophysiological mechanism.

The aim of our research was to study the association of the $-6754 \mathrm{G} / 5 \mathrm{G}$ (rs1799889) SNP of the SERPINE1 (PAI-1) gene and the Arg353Gln G>A (rs6046) SNP of the F7 gene with MetS in the Yakuts with COPD.

\section{Materials and methods}

A molecular-genetic examination of 200 COPD patients was conducted at the emergency department at the Republican Hospital No.2 in Yakutsk. The study was performed in the period between 2009 and 2013. The study was carried out within the framework of the project "Metabolic syndrome and chronic non-communicable diseases among the inhabitants of Yakutia" (State Project No. 11-01M.2009.). The study was approved by the Ethics Committee of the Yakut Science Center of Complex Medical Problems. Written informed consent was obtained from all patients.

Patients were divided into 2 groups. The main group (MG) consisted of 100 COPD patients (70 women and 30 men; mean age of $50.9 \pm 0.91$ years) with MetS, the comparison group (CG) included 100 COPD (80 women and 20 men; mean age of $48.9 \pm 1.35$ years) patients without MetS. All patients were of Yakut ethnicity and did not have kinship with each other.

Anthropometric parameters in $\mathrm{MG}$ and $\mathrm{CG}$ were as follows: BMI - $32.7 \pm 0.44 \mathrm{~kg} / \mathrm{m}^{2}$ and $23.2 \pm 0.35 \mathrm{~kg} / \mathrm{m}^{2}, \mathrm{WC}-102.9 \pm 0.95 \mathrm{~cm}$ and $77.2 \pm 0.96 \mathrm{~cm}, \mathrm{HC}-108.7 \pm 1.84 \mathrm{~cm}$ and $93.5 \pm 0.98 \mathrm{~cm}, \mathrm{WC} /$ $\mathrm{HC}$ ratio $-1.03 \pm 0.87$ and $0.8 \pm 0.01$, respectively. COPD diagnosis was based on the integral assessment of symptoms, medical history, health status, and spirometry values according to GOLD. MetS was diagnosed according to the IDF consensus criteria. ${ }^{(31)}$ The patients filled out a questionnaire approved by the ethics committee, which contained questions on these blocks: socio-demographic characteristics, anamnestic data, heredity research, behavior and health, a validated questionnaire for assessing respiratory symptoms, and a symptom scale of COPD patients (Paggiaro PL, 1998).

Total cholesterol (TC), low-density cholesterol (LDL-C), high-density lipoprotein cholesterol (HDL-C), and triglycerides (TG) were determined in plasma using biochemical analyzer Olympus AU 400 (Beckman Coulter, USA). Patients did not receive lipid-lowering treatment at the time of the examination.

DNA was isolated from peripheral blood leukocytes by a standard procedure based on phenol- chloroform extraction. Determination of gene polymorphism was performed by PCR using the Applied Biosystems amplifier and reagent kits SNPExpress (LITEH). DNA amplification for molecular detection of SNPs was performed by an allele-specific analysis. PCR products were analyzed on $2 \%$ agarose gel after staining with ethidium bromide and were visualized using a UV transilluminator.

Statistical processing and data analysis was carried out using the SPSS package (version 19). Baseline characteristics were summarized as frequencies and percentages for categorical variables and as mean \pm SD for continuous variables. The chisquare test was used to determine the deviation from HardyWeinberg equilibrium (HWE) $(P>0.05)$ and the differences in genotypes and alleles between groups. Odds ratios (ORs) and $95 \%$ confidence intervals (CIs) were calculated. We calculate ORs using multiplicative model for alleles and additive model for genotypes. Multiple comparisons were performed with one-way ANOVA and post-hoc Tukey HSD test. A probability value of $P<0.05$ was considered statistically significant.

\section{Results and Discussion}

The distribution of alleles and genotypes of studied SNPs in groups is shown in Table 1. The distribution of genotypes of studied SNPs was in Hardy-Weinberg equilibrium in all cases. Studying the SERPINE1 $-6754 \mathrm{G} / 5 \mathrm{G}$ SNP, we found the prevalence of a $4 \mathrm{G}$ allele in $\mathrm{MG}$, compared to $\mathrm{CG}(\mathrm{OR}=1.84$, $95 \%$ CI $1.23-2.74 ; \chi^{2}=9.06, P=0.003$ ). 
Table 1.

The distribution of alleles and genotypes of studied SNPs in MG and CG

\begin{tabular}{|c|c|c|c|c|c|c|c|c|}
\hline Gene & \multicolumn{2}{|c|}{ Allele Frequency } & OR $(95 \% \mathrm{CI})$ & $P$-value & \multicolumn{2}{|c|}{ Genotype Frequency } & OR $(95 \% \mathrm{CI})$ & $P$-value \\
\hline SERPINE1 & $\begin{array}{l}\text { 5G: 77(0.38) } \\
\text { 4G: } 123(0.62)\end{array}$ & $\begin{array}{c}\text { 5G: } 107(0.54) \\
\text { 4G: } 93(0.46)\end{array}$ & $\begin{array}{l}0.54(0.37-0.81) \\
1.84(1.23-2.74)\end{array}$ & 0.003 & $\begin{array}{l}\text { 5G/5G: } 14(0.14) \\
\text { 4G/4G: } 37(0.37) \\
\text { 5G/4G: } 49(0.49)\end{array}$ & $\begin{array}{l}\text { 5G/5G: } 27(0.27) \\
\text { 4G/4G: } 20(0.20) \\
\text { 5G/4G: } 53(0.53)\end{array}$ & $\begin{array}{l}0.44(0.21-0.90) \\
2.35(1.24-4.44) \\
0.85(0.49-1.48)\end{array}$ & 0.002 \\
\hline F7 & $\begin{array}{c}\operatorname{Arg} 353: 143(0.72) \\
C \ln 353: 57(0.28)\end{array}$ & $\begin{array}{c}\text { Arg353: } 142(0.71) \\
\text { Cln353: } 58(0.29)\end{array}$ & $\begin{array}{l}1.02(0.66-1.58) \\
0.98(0.63-1.50)\end{array}$ & 0.91 & $\begin{array}{c}\text { Arg353/Arg353: } \\
55(0.55) \\
\text { Cln353/Cln353: } \\
\text { 12(0.12) } \\
\text { Arg353/Cln353: } \\
\text { 33(0.33) }\end{array}$ & $\begin{array}{c}\text { Arg353/Arg353: } \\
52(0.52) \\
\text { Cln353/Cln353: } \\
10(0.10) \\
\text { Arg353/Cln353: } \\
38(0.38\end{array}$ & $\begin{array}{l}1.13(0.65-1.97) \\
0.80(0.45-1.44) \\
1.23(0.50-2.99)\end{array}$ & 0.92 \\
\hline
\end{tabular}

Incidence of the homozygous $4 \mathrm{G} / 4 \mathrm{G}$ mutation was rather high in $\mathrm{MG}$, compared to $\mathrm{CG}(\mathrm{OR}=2.35,95 \% \mathrm{CI}$ $\left.1.24-4.44 ; \chi^{2}=9.31, P=0.002\right)$. Thus, according to our data, the presence of MS in Yakut patients with COPD has been associated with the carrier of the $4 \mathrm{G} / 4 \mathrm{G}$ genotype. Similar data were obtained by V.Khavinson. ${ }^{(32)}$ Thus, the study showed that the presence of the $4 \mathrm{G} / 4 \mathrm{G}$ genotype significantly correlated with systolic hypertension and hyperglycemia in the Russian population. Our data also agree with earlier studies performed in Turkey and Italy. Thus, according to results by Berberoğlu and colleagues, ${ }^{(33)}$ in obese children, frequency of the $4 \mathrm{G} / 4 \mathrm{G}$ genotype was more than the $4 \mathrm{G} / 5 \mathrm{G}$ and $5 \mathrm{G} / 5 \mathrm{G}$ genotypes in the PAI-1 gene. Sartori and colleagues showed that the $4 \mathrm{G} / 5 \mathrm{G}$ polymorphism may influence PAI-1 expression in obesity, with a crucial role in central but not peripheral adiposity. ${ }^{(34)}$

Studying the F7 Arg353Gln SNP, we found the prevalence of an Arg253 allele in both groups (0.72 in MG and 0.71 in CG; $\left.\chi^{2}=0.01, P=0.91\right)$. Allelic frequency of the Gln353 mutation was 0.28 and 0.29 in $\mathrm{MG}$ and $\mathrm{CG}$, respectively $(P=0.91)$. The homozygous Gln353/Gln353 mutant genotype was rare in both groups ( 0.12 in $\mathrm{MG}$ and 0.10 in $\mathrm{CG}$; $\mathrm{OR}=1.23,95 \% \mathrm{CI}$ $0.50-2.99 ; \chi^{2}=0.01, P=0.92$ ). In our study, the F7 Arg353Gln SNP was not associated with protection against MetS in COPD patients.

An analysis of the association between components of MetS and the SERPINE1 -675 4G/5G SNP revealed significant differences in anthropometric parameters. The levels of BMI and WC were significantly greater in homozygous carriers of $4 \mathrm{G} / 4 \mathrm{G}$ compared to carriers of $5 \mathrm{G} / 4 \mathrm{G}$ and $5 \mathrm{G} 5 \mathrm{G}$ genotypes (Table 2). Similar results were obtained in the study by AlHamodi et al. ${ }^{(35)}$ : the Malaysian subjects with homozygous 4G/4G showed association with increased triglyceride levels $(P=0.007)$, BMI $(P=0.01)$ and diastolic blood pressure (BP) $(P=0.03)$.

In our study, the F7 Arg353Gln SNP was not associated with MetS in COPD patients of the Yakut ethnic group. In study by A.Reiner et al., ${ }^{(36)}$ young-to-middle-aged women (US population) carrying a $>$ or $=1$ copy of the low $\mathrm{F} 7$ expression level haplotype $\mathrm{C}$ (containing the $-401 \mathrm{~T} /-323 \mathrm{del} /-122 \mathrm{C}$ and Gln353 alleles) had a decreased BMI and an increased HDL-C level. According to a study by J.Pankow, ${ }^{(37)}$ the Gln353 allele was associated with lower FVII coagulant activity in moderately obese adults, but obtained results did not support the hypothesis that the Arg-Gln353 polymorphism interacts with the plasma triglyceride level in determining FVIIc.

Table 2.

MetS components in COPD patients of MG depending on the SERPINE1 -675 4G/5G SNP

\begin{tabular}{|l|c|c|c|c|}
\hline \multirow{2}{*}{ Variable } & $\begin{array}{c}5 \mathrm{G} / 5 \mathrm{G} \\
(\mathrm{n}=14) \\
{[1]}\end{array}$ & $\begin{array}{c}5 \mathrm{G} / 4 \mathrm{G} \\
(\mathrm{n}=49) \\
{[2]}\end{array}$ & $\begin{array}{c}4 \mathrm{G} / 4 \mathrm{G} \\
(\mathrm{n}=37) \\
{[3]}\end{array}$ & \multicolumn{1}{|c|}{ Statistics } \\
\cline { 2 - 5 } $\begin{array}{l}\mathrm{BMI} \\
\mathrm{kg} / \mathrm{m}^{2}\end{array}$ & $25.8 \pm 0.83$ & $27.8 \pm 0.59$ & $29.3 \pm 0.79$ & $\begin{array}{l}\mathrm{F}=3.5974 \mathrm{P}=0.0311 \\
\mathrm{P}_{1-3}=0.0283\end{array}$ \\
\hline $\begin{array}{l}\text { WC, } \\
\mathrm{cm}\end{array}$ & $83.8 \pm 1.93$ & $89.2 \pm 1.59$ & $95.3 \pm 1.99$ & $\begin{array}{l}\mathrm{F}=6.3574 \mathrm{P}=0.0025 \\
\mathrm{P}=0.0037 \\
\mathrm{P}_{2-3}=0.0346\end{array}$ \\
\hline $\begin{array}{l}\mathrm{HC}, \\
\mathrm{cm}\end{array}$ & $97.2 \pm 1.43$ & $99.8 \pm 1.19$ & $103.1 \pm 2.95$ & $\mathrm{~F}=1.3449 \mathrm{P}=0.2654$ \\
\hline WC/HC & $0.9 \pm 0.01$ & $0.9 \pm 0.01$ & $1.1 \pm 0.14$ & $\mathrm{~F}=1.7155 \mathrm{P}=0.1853$ \\
\hline $\begin{array}{l}\text { Heart } \\
\text { rate, } \\
\text { bpm }\end{array}$ & $76.9 \pm 1.57$ & $77.4 \pm 0.83$ & $75.4 \pm 1.04$ & $\mathrm{~F}=1.1869 \mathrm{P}=0.3095$ \\
\hline $\begin{array}{l}\text { Systolic } \\
\text { BP, } \\
\mathrm{mmHg}\end{array}$ & $123.5 \pm 3.63$ & $126.1 \pm 2.12$ & $131.3 \pm 2.75$ & $\mathrm{~F}=1.7928 \mathrm{P}=0.1720$ \\
\hline $\begin{array}{l}\text { Diastolic } \\
\text { BP, } \\
\mathrm{mmHg}\end{array}$ & $75.1 \pm 1.79$ & $76.6 \pm 1.19$ & $80.0 \pm 1.39$ & $\mathrm{~F}=2.6121 \mathrm{P}=0.0785$ \\
\hline $\begin{array}{l}\text { Glucose, } \\
\mathrm{mmol} / 1\end{array}$ & $5.3 \pm 0.11$ & $5.2 \pm 0.07$ & $5.4 \pm 0.16$ & $\mathrm{~F}=0.8575 \mathrm{P}=0.4274$ \\
\hline $\begin{array}{l}\text { TC, } \\
\mathrm{mmol} / 1\end{array}$ & $4.9 \pm 0.18$ & $5.3 \pm 0.12$ & $5.3 \pm 0.14$ & $\mathrm{~F}=1.4183 \mathrm{P}=0.2471$ \\
\hline $\begin{array}{l}\text { LDL-C, } \\
\mathrm{mmol} / 1\end{array}$ & $3.1 \pm 0.12$ & $3.4 \pm 0.09$ & $3.5 \pm 0.12$ & $\mathrm{~F}=1.9322 \mathrm{P}=0.1504$ \\
\hline $\begin{array}{l}\mathrm{HDL}-\mathrm{C}, \\
\mathrm{mmol} / 1\end{array}$ & $1.3 \pm 0.04$ & $1.4 \pm 0.04$ & $1.4 \pm 0.07$ & $\mathrm{~F}=0.5519 \mathrm{P}=0.5777$ \\
\hline $\begin{array}{l}\text { TG, } \\
\mathrm{mmol} / 1\end{array}$ & $1.3 \pm 0.09$ & $1.4 \pm 0.08$ & $1.6 \pm 0.11$ & $\mathrm{~F}=1.8720 \mathrm{P}=0.1593$ \\
\hline
\end{tabular}

\section{Conclusion}

Thus, in the Yakut ethnic group, the SERPINE1 -675 4G allele was predominant in COPD patients with MetS compared to COPD patients without MetS $(\mathrm{OR}=1.84,95 \% \mathrm{CI}$ 
$\left.1.23-2.74 ; \chi^{2}=9.06, P=0.003\right)$. Incidence of the homozygous 4G/4G mutation was rather high in COPD patients with MetS compared to COPD patients without MetS $(\mathrm{OR}=2.35,95 \% \mathrm{CI}$ $1.24-4.44 ; \chi^{2}=9.31, P=0.002$ ). The levels of BMI and $\mathrm{WC}$ were significantly greater in homozygous carriers of $4 \mathrm{G} / 4 \mathrm{G}$ compared to carriers of the $5 \mathrm{G} / 4 \mathrm{G}$ and $5 \mathrm{G} 5 \mathrm{G}$ genotypes. The homozygous F7 Gln353/Gln353 mutant genotype was rare in COPD patients with and without MetS (0.12 in MG and 0.10 in $\mathrm{CG} ; \mathrm{OR}=1.23,95 \%$ CI $\left.0.50-2.99 ; \chi^{2}=0.01, P=0.92\right)$. The F7 Arg353Gln SNP was not associated with protection against MS in COPD patients of the Yakut ethnic group.

\section{Conflict of interest}

The authors declare that they have no conflicts of interest to disclose.

\section{References}

1. WHO. Global surveillance, prevention and control of chronic respiratory diseases. Geneva, Switzerland: World Health Organization; 2007.

2. Murray CJ, LopezAD. Alternative projections of mortality and disability by cause 1990-2020: Global Burden of Disease Study. Lancet. 1997;349(9064):1498-504.

3. Lozano R, Naghavi M, Foreman K, Lim S, Shibuya $\mathrm{K}$, Aboyans V, et al. Global and regional mortality from 235 causes of death for 20 age groups in 1990 and 2010: a systematic analysis for the Global Burden of Disease Study 2010. Lancet. 2012;380(9859):2095-128. doi: 10.1016/S01406736(12)61728-0.

4. Global Initiative for Chronic Obstructive Lung Disease (GOLD, 2017 REPORT). Available from: http://goldcopd.org/ 5. Agusti A, Soriano JB. COPD as a systemic disease. COPD. 2008;5(2):133-38. doi: 10.1080/15412550801941349.

6. Barnes PJ, Celli BR. Systemic manifestations and comorbidities of COPD. Eur Respir J. 2009;33(5):1165-85. Eur Respir J. 2009;33(5):1165-1185.

7. Fabbri LM, Rabe KF. From COPD to chronic systemic inflammatory syndrome? Lancet. 2007;370(9589):797-9.

8. Shpagina LA, Gerasimenko ON, Shpagin IS, Zueva MA. [Endothelial dysfunction and vascular remodeling with arterial hypertension in combination with chronic obstructive pulmonary disease: new therapeutic targets]. Pulmonology. 2009;3:47-54. [Article in Russian].

9. Agusti A, Soriano JB. COPD as a systemic disease. COPD. 2008;5(2):133-8. doi: 10.1080/15412550801941349.

10. Minas M, Kostikas K, Papaioannou AI, Mystridou P, Karetsi E, Georgoulias P, et al. The association of metabolic syndrome with adipose tissue hormones and insulin resistance in patients with COPD without co-morbidities. COPD. 2011;8(6):414-20. doi:10.3109/15412555.2011.619600.

11. Watz H, Waschki B, Kirsten A, Müller KC, Kretchmar G, Meyer T, et al. The metabolic syndrome in patients with chronic bronchitis and COPD: frequency and associated consequences for systemic inflammation and physical inactivity. Chest. 2009;136(4):1039-1046. doi: 10.1378/chest.09-0393.

12. Wells CE, Baker EH. Metabolic syndrome and diabetes mellitus in COPD. Rabe KF, Wedzicha JA, Wouters EFM (eds). COPD and Comorbidity. European Respiratory Society, Sheffield. 2013:117-134.
13. Vujic T, Nagorni O, Maric G, Popovic L, Jankovic J. Metabolic syndrome in patients with chronic obstructive pulmonary disease: frequency and relationship with systemic inflammation. Hippokratia. 2016;20(2):110-114.

14. Franssen FME, O'Donnell DE, Goossens GH, Blaak EE, Schols AM. Obesity and the lung: 5. Obesity and COPD. Thorax. 2008;63(12):1110-7. doi: 10.1136/thx.2007.086827.

15. Palomo I, Moore-Carrasco R, Alarcon M, Rojas A, Espana F, Andres V, Gonzalez-Navarro H. Pathophysiology of the proatherothrombotic state in the metabolic syndrome. Front Biosc (Schol Ed). 2010;2:194-208.

16. Mamedov MN, Oganov RG. [Epidemiological aspects of the metabolic syndrome]. Kardiologiia. 2004; 44(9):4-8. [Article in Russian].

17. Loskutoff DJ, Curriden SA. The fibrinolytic system of the vessel wall and its role in the control of thrombosis. Ann NY Acad Sci. 1990;598:238-47.

18. Huang J, Sabater-Lleal M, Asselbergs FW, Tregouet D, Shin SY, Ding J, et al. Genome-wide association study for circulating levels of PAI-1 provides novel insights into its regulation. Blood. 2012;120(24):4873-81. doi: 10.1182/blood-2012-06-436188.

19. Kohler HP, Grant PJ. Plasminogen-activator inhibitor type 1 and coronary artery disease. N Engl J Med. 2000: 342(24):1792-801.

20. Incalcaterra E, Meli F, Muratori I, Corrado E, Amato C, Canino B, Ferrara F. Residual vein thrombosis and onset of postthrombotic syndrome: Influence of the $4 \mathrm{G} / 5 \mathrm{G}$ polymorphism of plasminogen activator inhibitor-1 gene. Thromb Res. 2014;133(3):371-4. doi: 10.1016/j.thromres.2013.12.032.

21. Hellwege JN, Palmer ND, Ziegler JT, Langefeld CD, Lorenzo C, Norris JM, et al. Genetic variants in selenoprotein $\mathrm{P}$ plasma 1 gene (SEPP1) are associated with fasting insulin and first phase insulin response in Hispanics. Gene. 2014;534(1):33-9. doi: 10.1016/j.gene.2013.10.035.

22. Rao LV, Rapaport SI. Activation of factor VII bound to tissue factor: a key early step in the tissue factor pathway of blood coagulation. Proc Natl Acad Sci U S A. 1988;85(18):6687-91.

23. Humphries SE, Lane A, Green FR, Cooper J, Miller GJ. Factor VII coagulant activity and antigen levels in healthy men are determined by interaction between factor VII genotype and plasma triglyceride concentration. Arterioscler Thromb. 1994;14(2):193-8.

24. Feng D, Tofler GH, Larson MG, O’Donnell CJ, Lipinska I, Schmitz C, et al. Factor VII gene polymorphism, factor VII levels, and prevalent cardiovascular disease: the Framingham Heart Study. Arterioscler Thromb Vasc Biol. 2000;20(2):593-600.

25. Mariani G, Bernardi F, Bertina R, Vicente VV, Prydz $\mathrm{H}$, Samama $M$, et al. Serum phospholipids are the main environmental determinants of activated factor VII in the most common FVII genotype. European Union Concerted Action "Clotart". Haematologica. 1999;84(7):620-6.

26. de Lange M, Snieder H, Ariens RA, Spector TD, Grant PJ. The genetics of haemostasis: a twin study. Lancet. 2001;357(9250):101-5.

27. Lam KS, Ma OC, Bourke C, Chan LC, Janus ED. Genetic influence of the R/Q353 genotype on factor VII activity is overwhelmed by environmental factors in Chinese patients with Type II (non-insulin-dependent) diabetes mellitus. Diabetologia.1998;41(7):760-6.

28. Iacoviello L, Di Castelnuovo A, De Knijff P, D'Orazio A, Amore C, Arboretti R, et al. Polymorphisms in the coagulation 
factor VII gene and the risk of myocardial infarction. N Engl J Med. 1998;338(2):79-85.

29. Ghaddar HM, Folsom AR, Aleksic N, Hearne LB, Chambless LE, Morrissey JH, Wu KK. Correlation of factor VIIa values with factor VII gene polymorphism, fasting and postprandial triglyceride levels, and subclinical carotid atherosclerosis. Circulation. 1998; 98(25):2815-21.

30. Hunault M, Arbini AA, Lopaciuk S, Carew JA, Bauer KA. The Arg353Gln polymorphism reduces the level of coagulation factor VII. In vivo and in vitro studies. Arterioscler Thromb Vasc Biol. 1997;17(11):2825-9

31. IDF Consensus Worldwide Definition of the Metabolic Syndrome, 2006. Available from: https:/www.idf.org/elibrary/consensus-statements/60-idfconsensus-worldwidedefinitionof-the-metabolic-syndrome.

32. Khavinson VKh, Strekalov DL, Lyshchev AA. [Analysis of the association of some genetic risk factors for coronary artery disease with indices of lipid metabolism and arterial pressure]. Kliniko-laboratornii konsilium. 2010;4:52-53. [Article in Russian].

33. Berberoğlu M, Evliyaoğlu O, Adiyaman P, Ocal G, Ulukol $\mathrm{B}$, Simşek F, et al. Plasminogen activator inhibitor-1 (PAI-1) gene polymorphism (-675 4G/5G) associated with obesity and vascular risk in children. J Pediatr Endocrinol Metab. 2006;19(5)741-8.

34. Sartori MT, Vettor R, De Pergola G, De Mitrio V, Saggiorato $\mathrm{G}$, Della Mea P, et al. Role of the $4 \mathrm{G} / 5 \mathrm{G}$ polymorphism of PaI1 gene promoter on PaI-1 levels in obese patients: influence of fat distribution and insulin-resistance. Thromb Haemost. 2001;86(5):1161-9.

35. Al-HamodiZH, Saif-Ali R, Ismail IS,Ahmed KA, Muniandy $\mathrm{S}$. Plasminogen activator inhibitor- $14 \mathrm{G} / 5 \mathrm{G}$ polymorphism is associated with metabolic syndrome parameters in Malaysian subjects. J Clin Biochem Nutr. 2012;50(3):184-9. doi: 10.3164/ jcbn.11-48.

36. Reiner AP, Carlson CS, Rieder MJ, Siscovick DS, Liu K, Chandler WL, et al. Coagulation factor VII gene haplotypes, obesity-related traits, and cardiovascular risk in young women. J Thromb Haemost. 2007;5(1):42-9.

37. Pankow JS, Folsom AR, Shahar E, Tsai MY, Jeffery RW, Wing RR. Weight-loss induced changes in plasma factor VII coagulant activity and relation to the factor VII Arg/Gln353 polymorphism in moderately obese adults. Thromb Haemost. 1998;79(4):784-9. 